\title{
A Critical study of Pramehahara effect of Dhaatri Nishe w.s.r. to Diabetes mellitus
}

\author{
Research Article
}

\section{Balavenkata Krishna $\mathbf{S}^{1^{*}}$, Sitaram Bulusu ${ }^{2}$}

1. PG Scholar, 2. Professor, Department of Dravyaguna. S.V. Ayurvedic College, Tirupati, A.P, India

\begin{abstract}
Nishaamlaki is a known Ayurvedic medicinal preparation which is found effective in controlling the Diabetes mellitus. But according to Astanga hridaya "Meheshudhaatrinishe" combination of Aamlaki and two Haridra drugs effectively controls Prameha.Here the word "NISHE" indicates two drugs i.e., Haridra and Daruharidra.The combination of Aamlaki (Emblica officinalis Linn.) Haridra (Curcuma longa Linn.) and Daruharidra (Berberis aristata D.C \& Coscinium fenestratum Colebr.) is to be considered as "Srestha" (Drug of choice) in Diabetes mellitus. India leads the world's largest number of diabetic subjects earning the dubious distinction of being termed the diabetes capital of the world. According to diabetes atlas 2008 published by Indian diabetic federation, the number of people with diabetes in India are currently around 40.9 million and is expected to rise to 69.9 million by 2025 unless urgent preventive measures are taken. In India, it is also $3^{\text {rd }}$ leading cause of death (After heart disease and cancer).It has turned out to be the biggest "silent killer" in today's world. The present research work is done on 60 patients dividing them into 2 groups.DH1 Group was given with Aamalaki, Haridra and Daruharidra \{Berberis aristata D.C\}, DH2 Group was given with Aamalaki, Haridra and Daruharidra \{Coscinium fenestratum Colebr.\}. Finally it is concluded that Daruharidra which is known botanically as Berberis aristata D.C is highly effective in controlling the blood sugar levels in combination with Aamalaki and Haridra than Coscinium fenestratum Colebr. in combinations with A amalaki and Haridra.
\end{abstract}

Keywords: Prameha, Diabetes Mellitus, Dhaatrinishe, Daruharidra.

\section{Introduction}

Diabetes mellitus is one of the most common metabolic disorders. According to WHO "Diabetes is a major threat to global public Health that is rapidly getting worse, and the biggest impact is on adults of working age in developing countries" The total number of recorded diabetes patients till the year 2000 are 171 million and expecting to be increased by 366 million by the year 2030 (1). Prameha may be compared to diabetes mellitus because of the similarities in etiology, pathogenesis, clinical features \& prognosis. Main Aim of Ayurveda is to cure the disease \& maintain health state, Ayurvedathe science of life-though has its own principles, is incorporating new theories and drugs in it and presenting them according to its principles. Nishaamlaki is already known in Ayurvedic field and found effective in certain cases of Diabetes mellitus,But according to Asthanga hridaya while describing Agryasangraha Meheshudhaatrinishe is said to be best for Diabetes mellitus(2).

Few scholars have contributed their best on this topic and proved Haridra and Aamalaki's role in

*Corresponding Author:

Balavenkata Krishna S

PG Scholar,

Department of Dravyaguna,

SV Ayurvedic College,

Tirupati, Andhra Pradesh. India

Email id: sunkesulabalavenkatakrishna@gmail.com
Prameha. The present study is designed to add one more step to those contributions adding of Daruharidra and Haridra along with Aamalaki. According to Acharya Indu while commentating on'Nishe', in Astangasamgraha he mentioned Nishe as Pindaharidra and Daruharidra (3). Pindaharidra is a synonym of Haridra. Hence Nishe means Haridradwaya. Considering this sutra, we further move forwarded and prepared Dhaatrinishe compound preparation with the combination of Haridradwaya and Aamalaki as per Indu.

Regarding the identity of Daruharidra, two plant spices are extensively used in the northern and southern parts of India. They are Berberis aristata D.C. and Coscinium fenestratum colebr. The present study is aimed to exactly identify the best combination in controlling Diabetes mellitus adding two varieties of Daruharidra to Haridra and Aamalaki in different combinations.

\section{Aims and objectives}

To study the Srestatha of Aamlaki, Haridra \& Daruharidra Combination to control prameha with reference to Diabetes mellitus as envisaged by Vagbhata $-I I$

To compare the effectiveness of Daruharidra (Coscinium fenestratum colebr. \& Berberis aristata D.C.) in combinations with A amalaki \& Haridra.

To evolve an effective drug having Pramehahara action as per the classical literature of Ayurveda. 
Clinical Study

Materials and Methods

The patients having classical symptoms of Diabetes Mellitus have been selected from OPD of PG Department Of Dravyaguna, S.V. Ayurvedic Hospital, TTD, Tirupati, irrespective of Sex, Religion, and Occupation etc.

A special detailed Clinical Pro forma has been prepared incorporating selected symptoms and signs based on both Ayurvedic and Modern description of the disease.

A detailed history has been taken and complete physical examination has been carried out.

\section{Plan of Study}

\section{Inclusion Criteria}

- Age group between 30-70 years.

- Fulfilment of Diagnostic Criteria.

\section{Diagnostic Criteria}

Signs and symptoms of DiabetesMellitus

Prabhutamutrata (Polyuria), Pipasaadhikayta (Polydipsia), Kshuda adhikya (Polyphagia), Kara pada daha (Burning sensation in feet \& hands), Swedaadhikyata (Perspiration), Daurbalya (Weakness) and Pindikodwestana (Cramps).

Standard criteria of National Diabetes Data group and W.H.O. for DM was adopted which are as follows: (Adopted by American Diabetic Association).

- Fasting blood glucose $\geq 126 \mathrm{mg} / \mathrm{dl}$ (or)

- Postprandial blood glucose $\geq 200 \mathrm{mg} / \mathrm{dl}$

\section{Exclusion Criteria}

- Patients suffering from any severe Systemic disease.

- Patients who are above below 30 years of Age and 60 Years of Age

- Type 1 DM inclusive dependent types of other DM cases

- Patients suffering from the complications of DM

\section{Method of Study/ Study Design:}

- Number of Groups

1. DH1 Group (A amalaki, Haridra and Daruharidra $\{$ Berberis aristata D.C $\})$

2. DH2 Group (Aamalaki, Haridra and Daruharidra \{Coscinium fenestratum Colebr.\})

- Dose - 500 mg 2 capsules B.D for 60 days

- Dosage form - Capsule

- Administration -Before meals

- Duration - 60 Days

- Vehicle - Water

\section{Diet \& Regimen}

Patients were asked to go for Aerobic exercises for 15-20 minutes in a day along with other routine physical works as a part of their regular activities. They were advised to avoid Kaphavardhaka A hara, day sleep, alcohol, high calorie diet etc.

\section{Follow-up}

All the patients were reviewed for their fasting blood sugars and postprandial blood sugars on $30^{\text {th }}$ day and $60^{\text {th }}$ day during the treatment.

\section{Investigations:}

- Fasting blood sugar levels (FBS)

- Postprandial blood sugar levels (PPBS)

\section{Criteria for the Assessment}

- Alleviation in the signs and symptoms of the disease as per Ayrvedic texts.

- Biochemical Investigations before and after the treatment.

\section{Subjective criteria}

The changes observed in the signs and symptoms were assessed by adopting suitable scoring pattern and the objective signs by using appropriate clinical tools. The detail assessment of clinical signs and symptoms are as follows:

\section{Polyuria (Prabhuta Mutrata)}

Grading

$3-5$ times per day, no or rarely at night

$6-8$ times per day, $1-2$ times per night

$9-11$ times per day, $3-4$ times per night

$>11$ times per day, $>4$ times per night

\section{2) Polydipsia (Pipasa - Adhikya)}

Absent (Taking 8-10 glass of water daily)

Patient is taking 10-15 glass/day \& getting satisfaction

Patient is taking 15- 20 glass/day \& not getting satisfaction

Patient is taking 20-25 glass/day \& not getting satisfaction

3) Polyphagia (Kshudha-Adhikya)

As usual / routine

Slightly increased (4 - 5times)/day

Moderately increased (6-7times)/ day

Markedly increased ( 8 - 9times)/day

4) Burning sensation in feet $\&$ hands (Kara-Pada daha)

No Pada daha

Kara-Pada daha not continuous

Kara-Pada daha continuous but

bearable \& not severe

Kara-Pada daha continuous, severe

\& Unbearable

5) Perspiration (Swedadhikya)

Sweating after some strenuous or heavy work or in hot $\&$ humid weather

Profuse sweating after moderate work and movement

Sweating after little extra work than routine and movement

Profuse sweating after routine work 
6) Weakness (Daurbalya)

Can do routine exercise/work

Can do moderate exercise with

hesitancy

Can do mild exercise only, with

difficulty

Cannot do mild exercise too

7) Cramps ( Pindikodveshtana)

No cramps

Cramps after walking more than $1 \mathrm{~km}$

Cramps after walking $1 / 2 \mathrm{~km}$

Inability in walking even $1 / 2 \mathrm{~km}$

\section{Objective criteria}

Bio-chemical investigations like Fasting blood sugars (FBS), postprandial blood sugars (PPBS) were performed before and after treatment.

Fasting blood glucose $\geq 126 \mathrm{mg} / \mathrm{dl}$ or Postprandial blood sugar levels $\geq 200 \mathrm{mg} / \mathrm{dl}$
Assessment of overall effect of Therapy :

The result obtained from individual patient was categorized according to the following grades:

\section{Statistical analysis:}

The gathered information was subjected to statistical analysis in terms of Mean, Standard Deviation and Standard Error. Paired " $\mathrm{t}$ " test was carried out at $\mathrm{p}<0.05, \mathrm{p}<0.01, \mathrm{p}<0.001$. The obtained results were interpreted as:

- Insignificant : $\mathrm{p} \geq 0.05$

- Significant : $\mathrm{p} \leq 0.05$

- Very significant : $\mathrm{p} \leq 0.001$

- Extremely significant : $\mathrm{p} \leq 0.0001$

\section{DH1 GROUP:}

This group consists of combination of $A$ amalaki, Haridra, Daruharidra (Berberis aristata D.C.)

$500 \mathrm{mg} 2$ Capsules with Water twice in a day half an hour before food for 60 days

Table 1. Showing subjective parameter results of DH1Group patients

\begin{tabular}{|c|c|c|c|c|c|c|c|c|c|c|}
\hline \multirow{2}{*}{ Parameter } & \multicolumn{2}{|c|}{ Mean } & \multicolumn{2}{c|}{ SD } & \multicolumn{2}{c|}{ SEM } & df & t value & p value & Significance \\
\cline { 2 - 10 } & B.T & A.T & B.T & A.T & B.T & A.T & & & & \\
\hline Polyuria & 2.45 & 0.70 & 0.51 & 0.73 & 0.11 & 0.16 & 19 & 17.616 & $\leq 0.0001$ & $\begin{array}{c}\text { Extremely } \\
\text { significant }\end{array}$ \\
\hline Polydipsia & 1.85 & 0.90 & 0.72 & 0.51 & 0.08 & 0.16 & 19 & 5.5964 & $\leq 0.0001$ & $\begin{array}{c}\text { Extremely } \\
\text { significant }\end{array}$ \\
\hline Polyphagia & 1.20 & 0.55 & 0.41 & 0.69 & 0.09 & 0.15 & 19 & 4.9509 & $\leq 0.0001$ & $\begin{array}{c}\text { Extremely } \\
\text { significant }\end{array}$ \\
\hline $\begin{array}{c}\text { Burning } \\
\text { sensation in } \\
\text { feet \& hands }\end{array}$ & 1.25 & 0.60 & 0.44 & 0.68 & 0.10 & 0.15 & 19 & 4.9509 & $\leq 0.0001$ & $\begin{array}{c}\text { Extremely } \\
\text { significant }\end{array}$ \\
\hline Perspiration & 1.20 & 0.45 & 0.41 & 0.69 & 0.09 & 0.15 & 19 & 6.0970 & $\leq 0.0001$ & $\begin{array}{c}\text { Extremely } \\
\text { significant }\end{array}$ \\
\hline Weakness & 1.45 & 0.55 & 0.51 & 0.69 & 0.11 & 0.15 & 19 & 6.2818 & $\leq 0.0001$ & $\begin{array}{c}\text { Extremely } \\
\text { significant }\end{array}$ \\
\hline Cramps & 1.20 & 0.65 & 0.41 & 0.75 & 0.09 & 0.17 & 19 & 4.8189 & $\leq 0.0001$ & $\begin{array}{c}\text { Extremely } \\
\text { significant }\end{array}$ \\
\hline
\end{tabular}

\section{DH2 group statistical data:}

This group consists of combination of Aamalaki, Haridra, Daruharidra (Coscinium fenestratum Colebr.)

$500 \mathrm{mg} 2$ Capsules with Water twice in a day half an hour before food for 60 days

Table 2.Showing subjective parameter results of DH2 Group patients

\begin{tabular}{|c|c|c|c|c|c|c|c|c|c|c|}
\hline & \multicolumn{2}{|c|}{ Mean } & \multicolumn{2}{c|}{ SD } & \multicolumn{2}{c|}{ SEM } & df & $\begin{array}{c}\text { t } \\
\text { value }\end{array}$ & p value & Significance \\
\hline & B.T & A.T & B.T & A.T & B.T & A.T & & & & \\
\hline Polyuria & 1.65 & 1.10 & 0.75 & 0.55 & 0.17 & 0.12 & 19 & 2.7729 & 0.0121 & Significant \\
\hline Polydipsia & 1.30 & 0.70 & 0.47 & 0.57 & 0.11 & 0.13 & 19 & 3.9428 & 0.009 & $\begin{array}{c}\text { Extremely } \\
\text { significant }\end{array}$ \\
\hline Polyphagia & 1.25 & 0.65 & 0.44 & 0.49 & 0.10 & 0.11 & 19 & 4.4853 & 0.0003 & $\begin{array}{c}\text { Extremely } \\
\text { significant }\end{array}$ \\
\hline $\begin{array}{c}\text { Burning } \\
\text { sensation in } \\
\text { feet \& hands }\end{array}$ & 1.25 & 0.65 & 0.44 & 0.59 & 0.10 & 0.13 & 19 & 3.9428 & 0.009 & $\begin{array}{c}\text { Extremely } \\
\text { significant }\end{array}$ \\
\hline Perspiration & 1.10 & 0.75 & 0.45 & 0.44 & 0.10 & 0.10 & 19 & 3.1986 & 0.0047 & $\begin{array}{c}\text { Very } \\
\text { Significant }\end{array}$ \\
\hline Weakness & 1.40 & 1.10 & 0.60 & 0.64 & 0.13 & 0.14 & 19 & 2.48536 & 0.0102 & Significant \\
\hline Cramps & 1.05 & 0.65 & 0.76 & 0.59 & 0.17 & 0.13 & 19 & 3.5590 & 0.0021 & $\begin{array}{c}\text { Very } \\
\text { Significant }\end{array}$ \\
\hline
\end{tabular}


Table 3.Showing results of DH1 Group Blood sugar levels

\begin{tabular}{|c|c|c|c|c|c|c|c|c|c|c|}
\hline & \multicolumn{2}{|c|}{ Mean } & \multicolumn{2}{c|}{ SD } & \multicolumn{2}{c|}{ SEM } & \multirow{2}{*}{ df value } & p value & Significance \\
\cline { 2 - 10 } & B.T & A.T & B.T & A.T & B.T & A.T & & & \\
FBS & 195.65 & 146.10 & 63.36 & 45.24 & 14.17 & 10.12 & 19 & 7.8545 & $\leq 0.0001$ & $\begin{array}{c}\text { Extremely } \\
\text { Significant }\end{array}$ \\
\hline PPBS & 223.35 & 174.95 & 57.17 & 35.82 & 12.78 & 8.01 & 19 & 6.6414 & $\leq 0.0001$ & $\begin{array}{c}\text { Extremely } \\
\text { Significant }\end{array}$ \\
\hline
\end{tabular}

Table 4.Showing results of DH2 Group Blood sugar levels

\begin{tabular}{|c|c|c|c|c|c|c|c|c|c|c|}
\hline & \multicolumn{2}{|c|}{ Mean } & \multicolumn{2}{c|}{ SD } & \multicolumn{2}{c|}{ SEM } & \multirow{2}{*}{ df } & \multirow{2}{*}{ value } & \multirow{2}{*}{ p value } & \multirow{2}{*}{ Significance } \\
\cline { 2 - 10 } & B.T & A.T & B.T & A.T & B.T & A.T & & \\
\hline FBS & 178.10 & 168.15 & 33.25 & 28.28 & 7.43 & 6.32 & 19 & 3.1482 & 0.0053 & $\begin{array}{c}\text { Very } \\
\text { significant }\end{array}$ \\
\hline PPBS & 219.05 & 204.05 & 53.46 & 45.84 & $\begin{array}{c}11.9 \\
5\end{array}$ & 10.25 & 19 & 3.0995 & 0.0059 & Significant \\
\hline
\end{tabular}

Table 5.Showing Subjective Parameter wise result in 2 groups

\begin{tabular}{|c|c|c|}
\hline Parameter & DH1 & DH2 \\
\hline Polyurea & $45 \%$ & $25 \%$ \\
\hline Polydipsia & $30 \%$ & $50 \%$ \\
\hline polyphagia & $55 \%$ & $55 \%$ \\
\hline $\begin{array}{c}\text { Burning sensation in feet and } \\
\text { Hands }\end{array}$ & $50 \%$ & $55 \%$ \\
\hline Perspiration & $65 \%$ & $50 \%$ \\
\hline Weakness & $55 \%$ & $40 \%$ \\
\hline Cramps & $50 \%$ & $53.33 \%$ \\
\hline
\end{tabular}

Graph No.1.Showing Parameter wise result in 2 groups

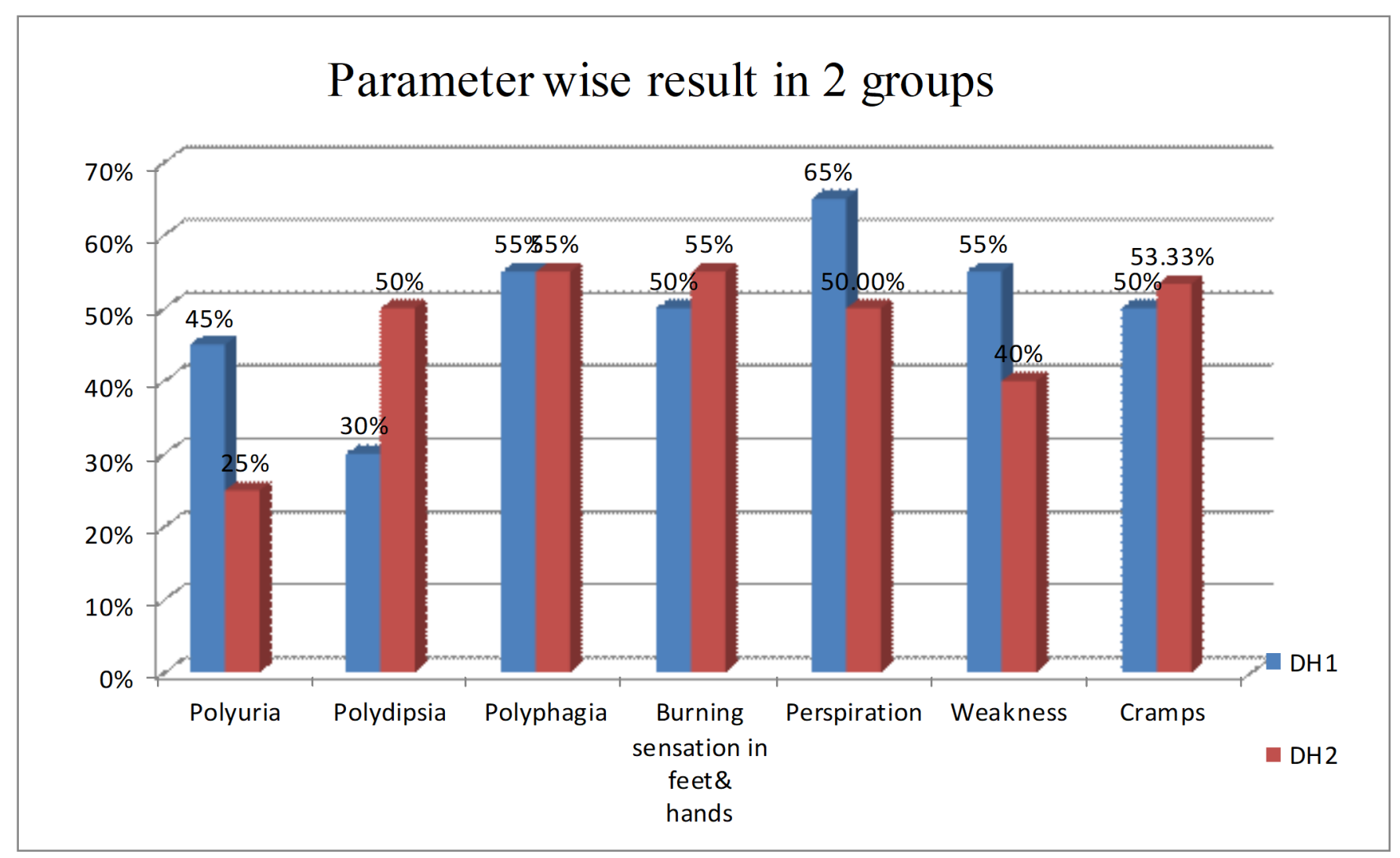

Assessment of overall effect of Therapy

The result obtained from individual patient was categorized according to the following grades: 
Table 6.Assessment of overall effect of Therapy

\begin{tabular}{|l|c|c|c|c|}
\hline & Improvement & Percentage of relief & DH1 & DH2 \\
\hline 1 & Marked improvement & $\geq 75 \%$ to $100 \%$ relief & 6 & 2 \\
\hline 2 & Moderate improvement & $\geq 50 \%$ up to $74.99 \%$ relief & 10 & 7 \\
\hline 3 & Mild improvement & $\geq 25 \%$ up to $49.99 \%$ relief & 4 & 10 \\
\hline 4 & No improvement & $<25 \%$ relief & 0 & 1 \\
\hline
\end{tabular}

Graph 2.Assessment of overall effect of Therapy

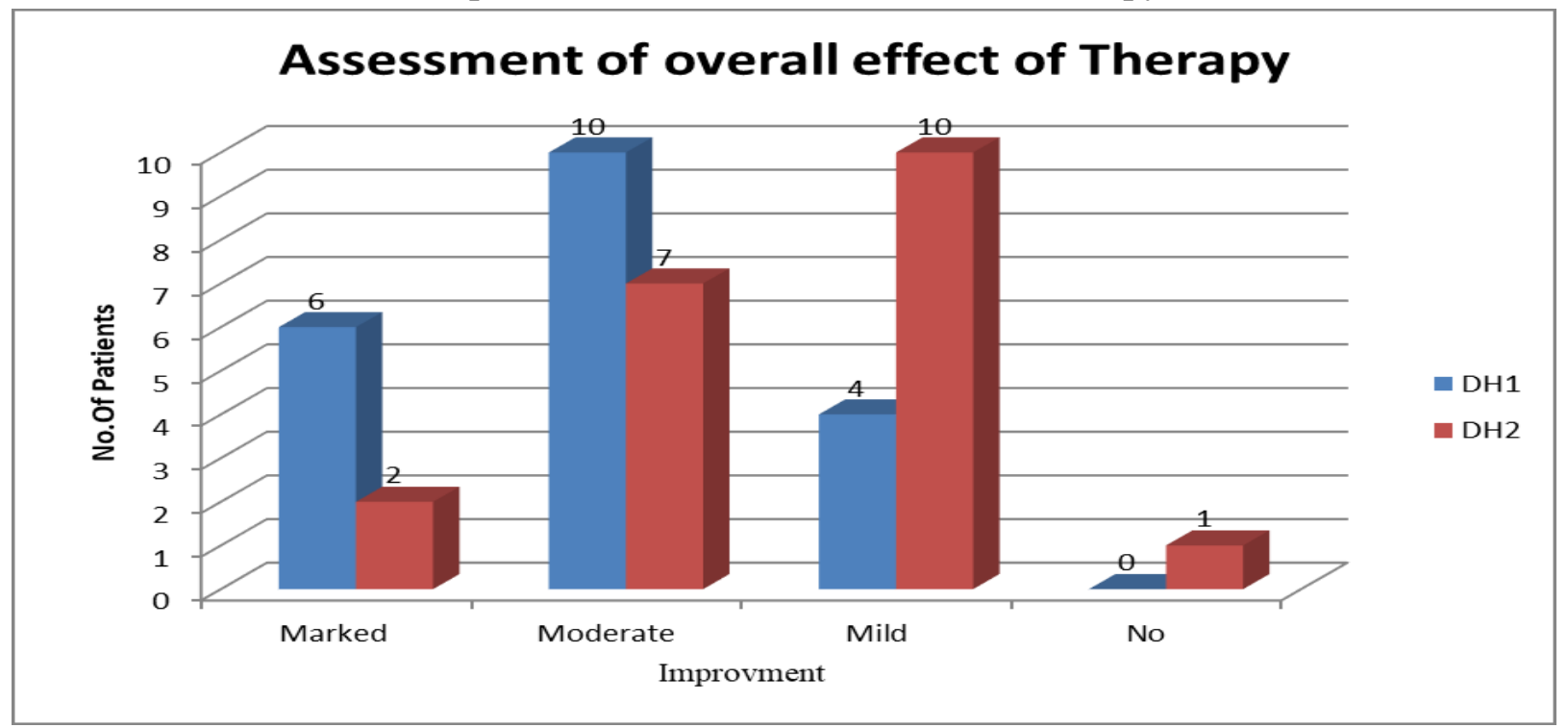

\section{Discussion}

The treatment continued for a period of 60 days for all the members of both of the groups and blood sugar levels are assessed at periodic intervals before and after treatment. At the end of 60 days the total results of the entire work was tabulated and were subjected for statistical study to clearly demonstrate the effect of 2 groups on the course of disease along with the values of significance.

At the end of 60 days fasting blood sugar levels of DH1 group patients have come down significantly, in comparison with the levels before the commencement of treatment. The t-test implied as 7.85 which is extremely significant at 0.01 levels. Postprandial blood sugar levels have come down significantly, in comparison with the levels before the commencement of treatment. The t-test implied as 6.64 which is extremely significant at 0.01 levels in the same group.

At the end of 60 days fasting blood sugar levels of $\mathrm{DH} 2$ group have come down significantly, in comparison with the levels before the commencement of treatment. The t-test implied as 3.14 which is very significant at 0.05 levels. Postprandial blood sugar levels have come down significantly, in comparison with the levels before the commencement of treatment. The t-test implied as 3.09 which is significant at 0.05 levels in the same group.

In the DH1 group 6 patients were showed marked improvement, 10 patients showed moderate improvement and 4 patients showed mild improvement in the total number of 20 patients.
In the DH2 group 2 patients showed marked improvement, 7 patients showed moderate improvement, 10 patients showed mild improvement and 1 patent showed no improvement in the total number of 20 patients.

\section{Probable mode of Action}

Haridra is used since time immemorial in different indications including Madhumeha. This drug is used both internally and externally also in healing ulcers due to Madhumeha. Haridra has got Katu, Tikta rasa, Katu vipaka, Ushna veerya and Ruksha guna(5). The therapeutic action of this drug in the management of the Prameha cannot be explained through the Rasapanchaka only but possible through Prabhava. Useful part of Haridra is Driedrhizome which is used clinically (6). Haridra contains curcumin, curcuminoids, other volatile oils and some coloring substances (7).Many modern research workers from different countries including institutes in India have reported about its hypoglycemic property in Type 2 diabetes.

Aamalaki is used extensively for many centuries as a household remedy for many ailments and also scientifically for its action on Madhumeha, which is due to its Rasayana property. This drug Aamalaki has got five Rasas except Lavana rasa but predominated by Amla rasa. The part used in this plant is its fruit rind. It has Guru, Ruksha gunas, Madhura vipaka and Seetha veerya(8). Chemically, Aamalaki contains many watersoluble tannins like Emblicannins, which are supposed to be the main active principles, behind decreasing the cellular resistance to insulin. The controversy of the 
presence of ascorbic acid and vitamin 'c' did not lessen its popular utility. Undoubtedly, Aamalaki is proved to be quite effective both experimentally and clinically as a promising hypoglycemic drug (9).

Daruharidra has been mentioned in context of Madhumeha treatment by Charaka, Susruta, Astang Sangraha and Later on Dhanvantari Nighantu, Shodal Nighantu, Madanpala Nighantu,Shaligram Nighantu, Bhavaprakasha Nighantu, Kaiyadeva Nighantu and Raj Nighantu have been mentioned. It is also an ingredient of various classical anti-Diabetic formulations. Raspanchaka of Daruharidra are -Tikta, Katu Rasa, Laghu, Ruksha Guna, Ushna Virya, Katu Vipaka (10).Daruharidra is acting by its Raspanchaka, The Katu and Tikta rasas pacify or balances the Bahudrava kapha and pitta respectively, By its Shoshan properties it reduce excessive meda, Kleda and Lasika etc; Laghu, Ruksha guna helps to normalize bahudrava kapha and indirectly stimulate Jatharagni and Dhatwagni.The Ushna Veerya further helps to bring vitiated Kapha and Vata Doshas to normal condition and stimulate Jatharagni as well as Dhatwagni. So in this way the Rasapanchaka of the Daruharidra normalizes the vitiated Kapha-Pitta - Vata, Dushya and Destructs the Samprapti.

Regarding the identity of Daruharidra, two plant spices are extensively used in the northern and southern parts of India. They are Berberis aristata D.C. and Coscinium fenestratum colebr. Surprisingly both the drugs have got common chemical constituents like Berberine and both are almost equally efficacious in the management of Diabetes mellitus.

\section{Conclusion}

Combination of Aamalaki, Haridra and Daruharidra clearly exhibited the anti-diabetic activity. They are useful as individual ingredients also.

After completing the duration of treatment, it was found that the compound preparation of Aamalaki, Haridra and north Indian market drug of Daruharidra showed the highest significant activity in reducing the blood sugar levels and the intensity of clinical symptoms in comparison with the South Indian market drug of Daruharidra.

As a sample study is very small it requires a larger group of patients for further evaluation.

\section{References}

1. Nicki R. Colledge, Brain R Walker, Stuart H. Ralston, Davidson's Principles \& Practice of medicine, 21ed, China, Elsevier limited.,2010,798p.

2. Srikantha murthy K.R., Vagbhata's Asthanga Hridyam Vol 3, Chowkamba Krishnadas Academy, Varanasi, $2012,420 p$

3. Jyotirmitra,Astanga Samgraha of Vrdhha Vagbhata with the Sasilekha Sanskrit commentary by Indu, Chowkambha Sanskrit series office, Varanasi,2012,122p.

4. Bapalal Vaidya, Some controversial drugs in Indian Medicine, Chaukambha Orientalia, Varanasi, 2014, $159 \mathrm{p}$.

5. Sastry.J.L.N, Illustrated Dravyaguna vijnana, Vol 2, Chaukambha Orientalia, Varanasi, 2014, 514p.

6. Bulusu Sitaram,Bhavaprakasha of Bhavamishra,Chaukhamba Orientalia, Varanasi, Reprint 2018,175p.

7. Kokate.C.K, Purohit A.P., Gokhale. S.B.,Pharmacogonosy,41ed,Pune,Nirali prakashan, 2008, 11.101p

8. Nishteswar.K, Koppula Hemadri, Dravyaguna vijnana, Chaukambha Sanskrit pratisthan, Delhi, 2013, p63

9. Maheswari Uddandi,Sitaram Bulusu, A Critical study of Nishamlaki on Madhumeha, Dept.of Dravyaguna, S.V.Ayurvedic college, Tirupathi, 2010.

10.Satishchandra Sankhyadhar, Rajnighantu of Sri Narahari Pandit,Chaukambha Orientalia,Varanasi, 2017, 265p. 